\title{
Perancangan dan Pembuatan Kecerdasan Buatan dengan Metode Alpha Beta Pruning pada Aplikasi Permainan Kartu Capsa
}

\author{
Christhofer Natalius Tandawidjaja \\ Program Studi Teknik Informatika \\ Fakultas Teknologi Informasi \\ Institut Informatika Indonesia \\ christhofernatalius@gmail.com
}

\author{
Hermawan Andika \\ Program Studi Teknik Informatika \\ Fakultas Teknologi Informasi \\ Institut Informatika Indonesia \\ andika@ikado.ac.id
}

\author{
Edwin Meinardi \\ Program Teknik Informatika \\ Fakultas Teknologi Informasi \\ Institut Informatika Indonesia \\ edwin@ikado.ac.id
}

\begin{abstract}
Abstrak- Game atau yang biasa disebut permainan merupakan aktivitas terstruktur atau semi terstruktur yang biasanya bertujuan untuk menghibur. Pada tugas akhir ini penulis mengembangkan permainan android dengan judul King and Slave Capsa yang merupakan salah satu media hiburan. Pengembangan permainan ini akan menggunakan framework Starling yang menggunakan bahasa Action Script 3 dengan bantuan aplikasi Adobe Flash Builder, dan menggunakan Alpha Beta Pruning sebagai kecerdasan buatannya. Adanya beberapa fitur dalam permainan seperti fitur permainan offline melawan komputer, permainan online dan google play achievement yang membuat permainan menjadi menarik untuk dimainkan.
\end{abstract}

Kata Kunci - Game, Android, Big 2, Kartu, Capsa, Starling, Action Script 3, Adobe Flash Builder, Alpha Beta Pruning, Artificial intelligence.

\section{PENDAHULUAN}

Perkembangan teknologi saat ini kian berkembang pesat, komputerisasi pun merambah ke segala bidang. Permainan yang dulunya dimainkan secara manual, banyak diadaptasi kedalam komputer, contohnya permainan catur dan permainan kartu. Permainan kartu memiliki banyak sekali jenis dan variasinya. Permainan Big Two atau yang lebih dikenal di Indonesia dengan sebutan Capsa Banting merupakan salah satu dari jenis permainan kartu remi yang sangat umum dan populer dimainkan di kalangan baik anakanak, remaja, dan dewasa

Permainan kartu ini diciptakan di daratan Cina sekitar tahun 1980, dan menjadi sangat terkenal di Shanghai, Hongkong, Taiwan, Filipina dan Singapura dan juga menyebar ke daerah barat. Permainan Capsa ini mempunyai beberapa nama, di Cina permainan ini dikenal dengan nama Choi Dai Di atau Bu Bu Gao Sheng. Di Amerika dan Australia dikenal dengan nama Big Two, Big Deuce, atau Deuce.

Keunggulan membuat game kartu di smartphone adalah adanya tampilan yang atraktif, dan tidak membutuhkan orang lain sebagai musuh karena dapat diprogramkan menggunakan kecerdasan buatan yang dapat berperan sebagai musuh dan dapat dimainkan dimanapun.
Algoritma yang diterapkan pada aplikasi ini adalah Alpha Beta Pruning. Algoritma Alpha Beta Pruning digunakan atas dasar pertimbangan bahwa algoritma ini terbukti handal dan telah diterapkan dengan baik untuk game catur dan tic-tactoe.

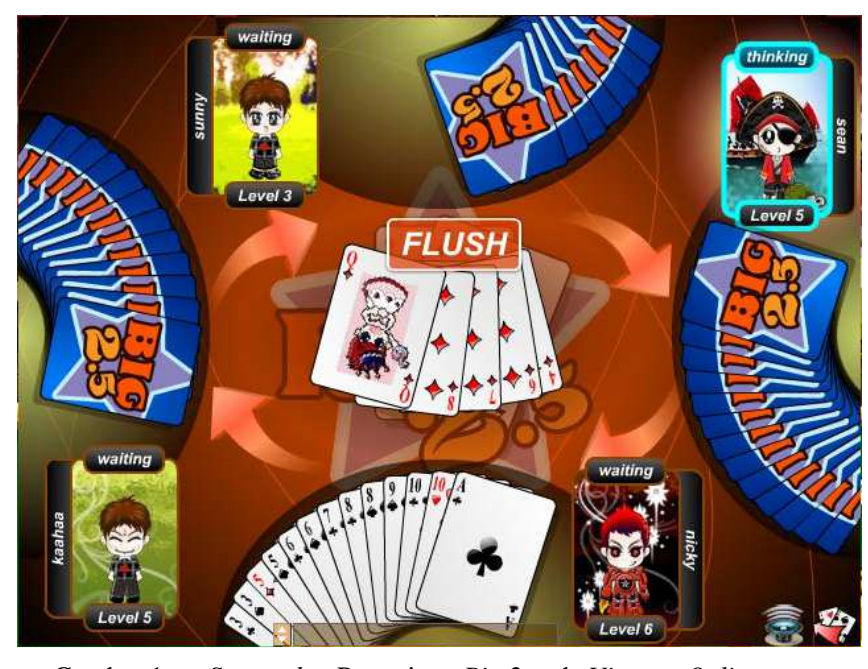

Gambar 1. Screenshot Permainan Big 2 pada Viwawa Online

\section{LANDASAN TEORI}

\subsection{Permainan Big Two}

Permainan capsa banting umumnya dimainkan oleh empat orang. Perangkat yang dibutuhkan adalah 52 kartu tanpa joker. Di awal permainan, ke-52 kartu ini dibagikan sampai habis. Jadi setiap pemain mendapat 13 kartu. Big 2 dikenal juga sebagai capsa banting, disebut banting karena saat mengeluarkan kartu, sebab saat mengeluarkan kartu, kita membantingnya.

Untuk mendukung analisis kebutuhan sistem diperlukan penjelasan rules / peraturan yang harus diikuti dalam permainan Big 2 sebagai berikut: [1]

a. Menggunakan kartu remi yang berjumlah 52 buah.

b. Urutan rank dari yang terkecil adalah $3,4,5,6,7,8,9,10, \mathrm{~J}, \mathrm{Q}, \mathrm{K}, \mathrm{A}, 2$. 
c. Urutan gambar / suits kartu dimulai dari yang terkecil adalah diamond $\$$, club heart $\boldsymbol{\bullet}$, spade

d. Kartu dibagikan merata kepada empat pemain secara tertutup sehingga setiap pemain akan mendapat 13 kartu. Pemain yang mendapatkan giliran pertama adalah pemain yang mempunyai kartu $3 \diamond$ lalu secara bergantian saling membuang kartu untuk melawan kartu sebelumnya.

e. Pemain yang kartunya habis terlebih dahulu dialah yang menang.

Dalam permainan capsa banting ini juga ada pembagian kombinasi kartu yang dapat dimainkan. Pemain hanya boleh memainkan kartu dengan kombinasi yang sama tetapi memiliki nilai lebih besar. Kombinasi kartu adalah sebagai berikut:

a. Single

Kartu bernilai berapapun yang berjumlah 1 buah.

b. Pair

Sepasang kartu yang memiliki rank yang sama.

c. Three of a Kind

Tiga buah kartu dengan rank yang sama.

d. Five cards hands

Lima buah kartu dengan kombinasi rank dan suits tertentu sehingga membentuk suatu pola. Terdapat 6 jenis Five Cards dengan kekuatan yang berbeda-beda.

Urutan kekuatan Five cards adalah sebagai berikut:

1. Straight

kartu yang memiliki ranking berurutan.

2. Flush

Lima buah kartu dengan suit yang sama.

3. Full house

Kombinasi Pair dengan Threes.

4. Four of a kind

Empat buah kartu dengan ranking yang sama.

5. Straight flush

Lima buah kartu dengan rank berurutan dan memiliki suits yang sama.

6. Royal Flush

Kombinasi 10-J-Q-K-A dengan suits yang sama.

Straight dapat dilawan dengan Flush, sedangkan Flush tidak dapat dilawan dengan Straight. Royal Straight Flush dengan spade adalah yang terkuat dan tidak dapat dikalahkan.

\subsection{Kecerdasan Buatan}

Kecerdasan buatan atau lebih dikenal sebagai Artificial Intelligence, memiliki beberapa definisi, antara lain:

a. Kecerdasan buatan atau artificial intelligence merupakan salah satu bagian ilmu komputer yang membuat agar mesin (komputer) dapat melakukan pekerjaan seperti dan sebaik yang dilakukan oleh manusia. [2]

b. Artificial Intellegence adalah sebagian dari komputer sains yang mempelajari (dalam arti merancang) sistem komputer yang berintelegensi, yaitu sistem yang memiliki karakteristik berpikir seperti manusia. [3] c. Kecerdasan buatan merupakan sebuah studi tentang bagaimana membuat komputer melakukan hal-hal yang pada saat ini dapat dilakukan lebih baik oleh manusia. [4]

\subsection{Minimax}

Algoritma minimax merupakan salah satu algoritma yang sering digunakan untuk game kecerdasan buatan yang menggunakan teknik depth first search (DFS) dalam pencariannya pada pohon dengan kedalaman terbatas. Algoritma minimax digunakan untuk memilih langkah terbaik, dimana kedua pemain akan saling berusaha untuk memenangkan permainan. Selain itu, algoritma minimax ini bekerja secara recursive dengan mencari langkah yang akan membuat lawan mengalami kerugian minimum. Algoritma minimax mendeskripsikan kondisi apabila terdapat pemain yang mengalami keuntungan, pemain lain akan mengalami kerugian senilai dengan keuntungan yang diperoleh lawan dan sebaliknya.

Algoritma minimax akan melakukan pengecekan pada seluruh kemungkinan yang ada, sehingga akan menghasilkan pohon permainan yang berisi semua kemungkinan permainan tersebut [5]. Dengan pohon permainan ini setiap pemain mengetahui langkah-langkah yang mungkin diberikan pada situasi permainan saat ini. Sehingga untuk setiap langkah dan semua langkah selanjutnya dapat diketahui. Dalam repersentasi pohon pada algoritma minimax, terdapat dua jenis simpul, yaitu simpul min dan simpul max. Max akan memilih langkah dengan nilai tertinggi dan min akan memilih langkah dengan nilai terendah [2]. Dalam penentuan keputusan max/min tersebut dibutuhkan suatu nilai yang merepresentasikan kerugian atau keuntungan yang akan diperoleh jika langkah tersebut dipilih. Untuk itulah disini digunakan sebuah fungsi heuristik.

Fungsi heuristik yang digunakan algoritma ini adalah fungsi heuristik statis [3]. Fungsi heuristik digunakan untuk mengevaluasi nilai sebagai nilai yang merepresentasikan hasil permainan yang akan terjadi jika langkah tersebut dipilih. Dari nilai-nilai heuristik inilah komputer akan menentukan simpul mana dari pohon permainan yang akan dipilih, tentunya simpul yang akan dipilih tersebut adalah simpul dengan nilai heuristik yang akan menuntun permainan ke hasil akhir yang menguntungkan bagi komputer.

\subsection{Alpha Beta Pruning}

Dalam algoritma minimax, banyak terjadi kejadian dimana terjadi pengecekan sebuah simpul yang seharusnya tidak dicek karena tidak akan mempengaruhi hasil akhir. Untuk menghindari hal yang demikian, telah dibuat suatu algoritma minimax yang lebih optimal, yaitu algortima alpha beta pruning.

Hasil algoritma alpha beta pruning sendiri tidak berubah dari algoritma minimax, yang berubah hanya traversal-nya yang lebih sedikit. Algoritma alpha beta pruning memanfaatkan dua nilai, yaitu alpha dan beta. Nilai alpha menunjukkan skor pilihan terbaik yang bisa diambil pemain Max, dan nilai beta menunjukan skor pilihan terbaik 
yang bisa diambil pemain Min. Pruning dilakukan ketika simpul yang sedang ditinjau pada pemain Max, yaitu n, memiliki skor yang lebih rendah daripada alpha, maka n tidak perlu ditinjau lagi berikutnya. Hal yang sama dilakukan pada pemain Min memakai nilai beta.

\section{ANALISA DAN DESAIN SISTEM}

\subsection{Use Case Diagram}

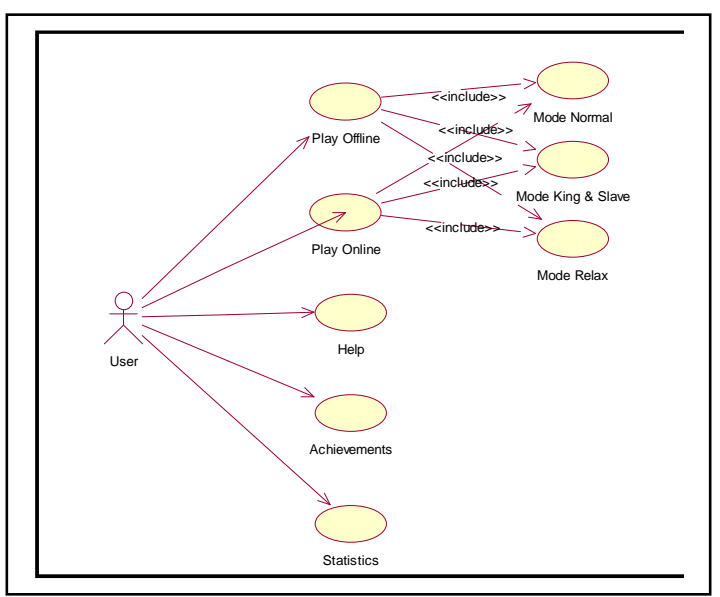

Gambar 2. Use Case Diagram

Pada aplikasi ini, pengguna dapat memilih 5 menu yaitu :

- Play Offline : Pengguna bermain bersama 3 AI.

kartu di tangan, yang kemudian akan dinyatakan sebagai pemenang pada ronde tersebut.

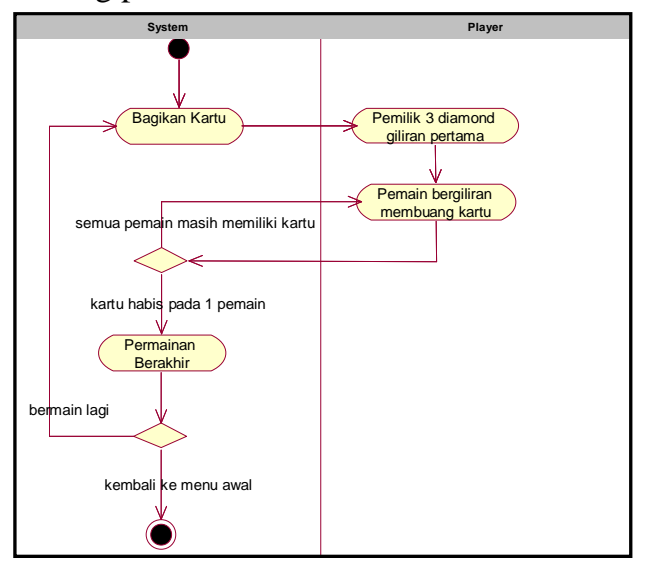

Gambar 3. Activity Diagram Mode Normal

b. Mode King \& Slave

Mode King \& Slave ini hampir sama dengan mode Normal. Permainan akan berhenti jika salah satu pemain sudah tidak memiliki kartu di tangan, yang kemudian akan dinyatakan sebagai King. Lalu pemain yang memiliki sisa kartu paling sedikit akan dinyatakan sebagai Queen, pemain yang memiliki sisa kartu terbanyak akan dinyatakan sebagai Slave 2, dan pemain lainnya akan dinyatakan sebagai Slave 1. Lalu pada ronde berikutnya, setelah kartu dibagikan, Slave 2 harus
- Play Online : Pengguna bermain dengan pemain lain secara online.

- Help : Pengguna dapat melihat aturan dan cara bermain Capsa.

- Statistic : Pengguna dapat melihat skor dan jumlah menang/kalah.

- Achievements : Pengguna dapat melihat pencapaian yang ada pada aplikasi ini pada akun Google Play Games pengguna.

Untuk membuat permainan semakin menarik dan seru, aplikasi permainan kartu King and Slave Capsa ini akan memiliki 3 mode permainan, yaitu mode Normal, mode King \& Slave, dan mode Relax yang dapat dimainkan dengan AI maupun dengan pemain lain secara online. Mode permainan tersebut memiliki cara bermain yang serupa dan tujuan yang sama yaitu adu cepat dalam menghabiskan kartu di tangan. Perbedaan dari ketiga mode tersebut terletak pada kondisi permainan berhenti dan jumlah pemenang yang dihasilkan.

\subsection{Activity Diagram}

Activity Diagram menggambarkan urutan aktivitas dalam sebuah proses. Berikut akan dijelaskan mode permainan Normal, King \& Slave, dan Relax dalam bentuk Activity Diagram dan perbedaan antara ketiga mode tersebut. Selanjutnya juga akan dijelaskan permainan online dan inisialisasi ruangan dalam bentuk Activity Diagram.

a. Mode Normal

Mode Normal adalah mode yang biasa digunakan pada aplikasi permainan Big 2 yang lain. Permainan akan berhenti jika salah satu pemain sudah tidak memiliki memberikan dua kartu tertingginya kepada King, lalu King akan memberikan dua kartu bebas. Slave 1 harus memberikan satu kartu tertingginya kepada Queen, lalu Queen akan mengembalikan satu kartu miliknya.

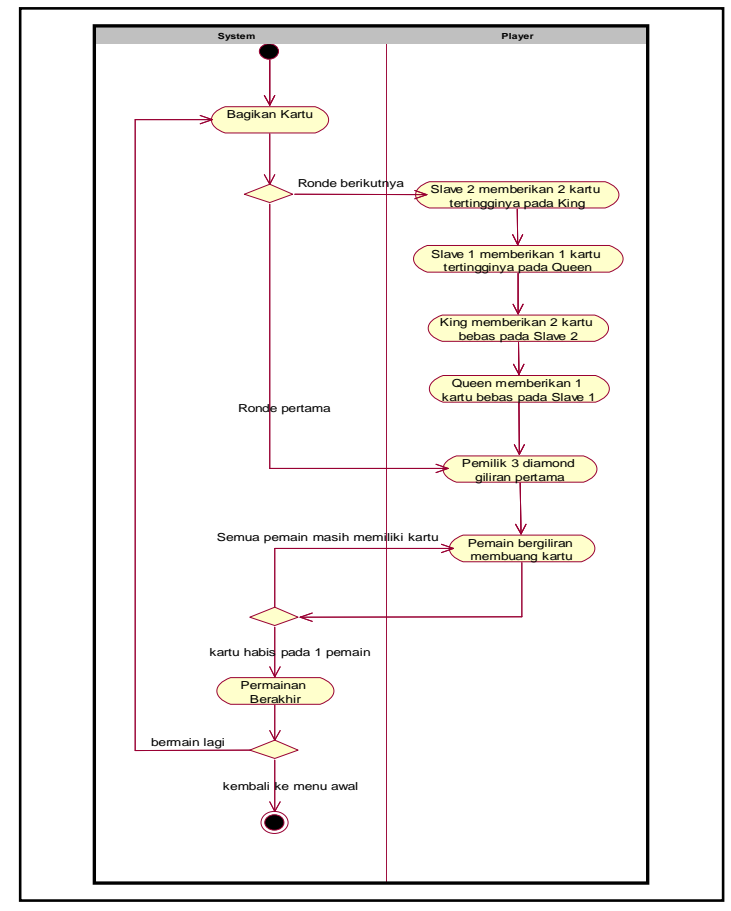

Gambar 4. Activity Diagram Mode King \& Slave 
c. Mode Relax

Mode Relax memiliki kondisi permainan berhenti yang berbeda dari mode Normal dan mode King \& Slave. Permainan tidak berhenti dan berlanjut terus hingga tiga pemain sudah habis kartunya dan tersisa satu pemain saja yang masih memiliki kartu.

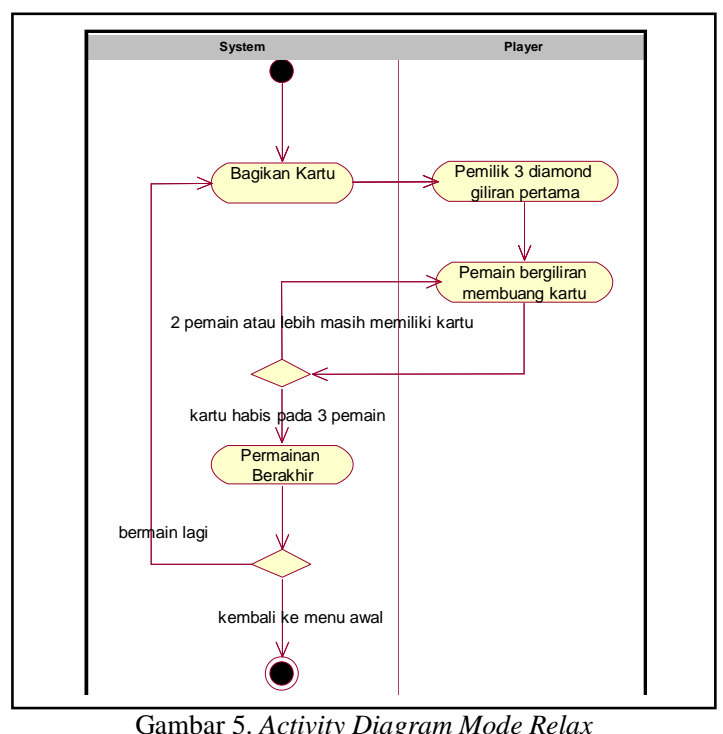

\subsection{Permainan Online}

Permainan online juga memiliki mode permainan yang sama, yaitu Normal, King \& Slave dan Relax. Pemain dapat memilih untuk bergabung dengan room yang sudah ada atau membuat room sendiri. Mode permainan dipilih saat akan membuat room. Satu room harus berisi 4 orang untuk memulai permainan.

Untuk bermain online, pemain diminta menginputkan nama yang unik pada halaman login play online kemudian menekan tombol Enter. Setelah berhasil melakukan login, aplikasi akan menampilkan halaman lobby yang berisi daftar room yang ada. Pemain kemudian dapat membuat atau bergabung dengan room yang sudah ada.

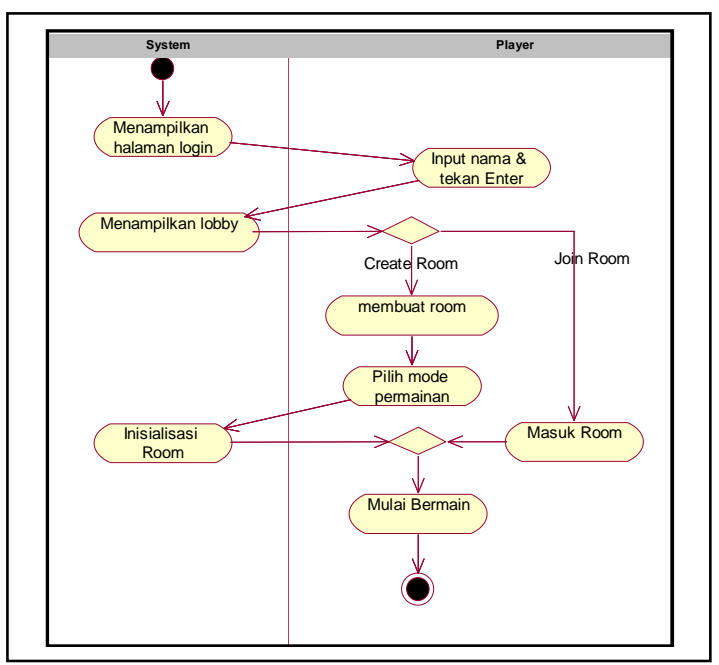

Gambar 6. Activity Diagram Permainan Online a. Lobby

Halaman lobby ditampilkan setelah pemain menginputkan nama dan menekan tombol Enter pada halaman online login. Lobby menampilkan daftar room yang ada.

b. Room

Room atau ruangan adalah tempat pemain berkumpul dan bermain bersama. Permainan dapat dimulai jika terdapat 4 orang dalam satu ruangan dan ketiga pemain tersebut sudah melakukan Ready. Owner / pemilik room kemudian dapat memulai permainan.

Setelah permainan dimulai, tidak ada pemain lain yang dapat masuk walaupun jumlah pemain kurang dari empat. Server kemudian akan menangani interaksi antar pemain yang ada dalam room.

\subsection{Scoring}

Setiap selesai satu ronde permainan, pemain akan dinilai berdasarkan sisa kartu ditangan. Pemain yang menang mendapat nilai positif, dan jika kalah maka nilai yang didapat bernilai negatif. Pemain yang meninggalkan permainan akan mendapat nilai negatif dan dikalikan dua. Nilai untuk pemenang adalah berdasarkan sisa kartu musuh, dan nilai untuk pemain yang kalah berdasarkan sisa kartu ditangan permain tersebut. Berikut penjelasan tentang scoring dalam bentuk flowchart.

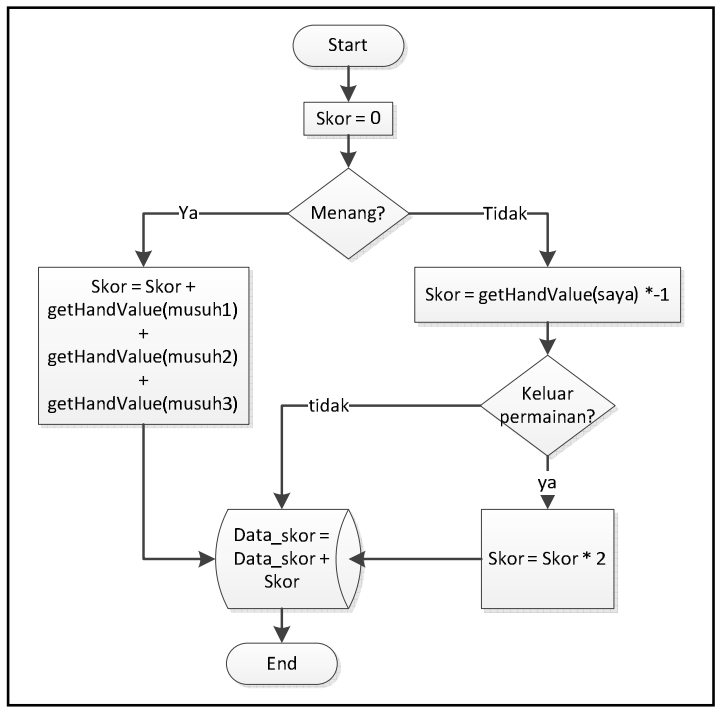

Gambar 7. Flowchart perhitungan skor

Adapun nilai pada setiap kartu dibuat berbeda. Berikut adalah nilai kartu untuk perhitungan skor.

Tabel 1. Nilai Kartu untuk Scoring
\begin{tabular}{|c|c|}
\hline \multirow{1}{*}{ Kartu } & Nilai \\
\hline $3-10$ & 1 \\
\hline J & 2 \\
\hline Q & 3 \\
\hline K & 4 \\
\hline A & 5 \\
\hline 2 & 10 \\
\hline
\end{tabular}




\subsection{Penerapan Artificial Intelligence}

Dalam algoritma Minimax, komputer akan menghitung kemungkinan langkah yang dapat diambil oleh komputer dan lawan, untuk mencari nilai SBE (Static Board Evaluator). SBE adalah nilai kerugian yang akan dialami pada langkah yang diambil. Semakin besar SBE maka semakin besar kemungkinan mengalami kekalahan. Lawan dalam permainan capsa banting ini adalah 3 pemain.

Dalam permainan capsa banting, pemain tidak dapat melihat kartu yang dimiliki oleh lawan. Maka untuk menghitung SBE, diperlukan virtual hand. Virtual Hand adalah kartu simulasi berisi semua kartu dalam deck, dikurangi kartu di tangan dan kartu yang telah dibuang. Sehingga virtual hand akan berisi semua kartu yang ada pada tangan lawan.

Langkah utama dalam permainan capsa banting ini dibagi menjadi 2 yaitu, first turn (giliran pertama) dan second turn / not first turn (bukan giliran pertama). Kondisi first turn dan second turn memiliki perbedaan besar, dalam first turn pemain bebas mengeluarkan kartu apa saja (asalkan memenuhi syarat), sehingga pemain bebas untuk mengeluarkan single, pair, threes atau five card. First turn didapat oleh pemilik kartu $3 \triangleleft$ saat permainan dimulai, dan saat pemain mengeluarkan kartu kemudian 3 pemain lain melakukan pass.

Sedangkan dalam second turn pemain harus mengeluarkan kartu sesuai dengan kategori kartu yang dikeluarkan oleh pemain yang melakukan first turn. Misalnya jika pemain A yang mendapat first turn mengeluarkan pair, maka pemain $\mathrm{B}, \mathrm{C}$, dan $\mathrm{D}$ harus mengeluarkan pair yang bernilai lebih besar, tidak boleh mengeluarkan single, threes, atau five card. Jika tidak dapat mengeluarkan pair dengan nilai lebih besar, maka pemain tersebut harus melakukan pass.

\section{A. Perhitungan Nilai Kartu}

Setiap kartu atau kombinasi kartu mempunyai nilai tersendiri yang mengukur seberapa berharganya kartu tersebut, sehingga diperlukan adanya prioritas dalam urutan pengeluaran kartu. Untuk mendapatkan nilai kartu yang unik (tidak ada yang berulang) dan terurut dengan selisih 1 angka, setelah dilakukan observasi pada saat pengurutan kartu dalam permainan yang sebenarnya, dihasilkan rumus:

$$
\begin{aligned}
& \mathrm{C}=\text { nilai kartu } \\
& \mathrm{r}=\text { rank dari kartu }(3,4,5, \ldots, 15) \\
& \mathrm{s}=\text { suits dari kartu }(\bullet=1,=2, \vee=3,=4)
\end{aligned}
$$$$
C=(r * 4)+s
$$

Angka 4 diperoleh dari jumlah suits yang ada, dan terakhir nilai kartu ditambahkan dengan nilai suits $(\diamond=1$, $=2, \boldsymbol{\vee}=3, \mathbf{s}=4$ ) agar nilai kartu bertambah sebanyak 1 angka. Kartu J memiliki rank 11, kartu Q memiliki rank 12, kartu K memiliki rank 13, kartu A memiliki rank 14, dan kartu 2 memiliki rank 15.
Tabel 2. Tabel Penilaian Kartu

\begin{tabular}{|c|r|r|r|}
\hline Kartu & \multicolumn{1}{|c|}{ r } & \multicolumn{1}{c|}{ s } & \multicolumn{1}{c|}{ C } \\
\hline 3 & 3 & 1 & 13 \\
\hline 3 & 3 & 2 & 14 \\
\hline $3 \boldsymbol{*}$ & 3 & 3 & 15 \\
\hline 3 & 3 & 4 & 16 \\
\hline 4 & 4 & 1 & 17 \\
\hline 4 & 4 & 2 & 18 \\
\hline 4 & 4 & 3 & 19 \\
\hline 4 & 4 & 4 & 20 \\
\hline & $\ldots$ & $\ldots$ & $\ldots$ \\
\hline A & 14 & 1 & 57 \\
\hline A & 14 & 2 & 58 \\
\hline A & 14 & 3 & 59 \\
\hline A & 14 & 4 & 60 \\
\hline 2 & 15 & 1 & 61 \\
\hline 2 & 15 & 2 & 62 \\
\hline 2 & 15 & 3 & 63 \\
\hline & 15 & 4 & 64 \\
\hline
\end{tabular}

B. Perhitungan Nilai Kombinasi Kartu

Aturan dalam permainan capsa banting memungkinkan seorang pemain untuk mengeluarkan lebih dari satu buah kartu, seperti pair, threes, dan five cards. Tiap kombinasi kartu tersebut harus memiliki nilai kelayakan sendiri. Five Card Hands harus memiliki nilai lebih tinggi daripada single dan pair karena dapat membuang kartu lebih banyak dalam satu kali giliran.

$$
\begin{aligned}
& \mathrm{K}=\mathrm{C} 1+\mathrm{C} 2+\ldots+\mathrm{Cn} \\
\mathrm{K}= & \text { nilai kombinasi kartu } \\
\mathrm{C}= & \text { nilai kartu }((\mathrm{r} * 4)+\mathrm{s}) \\
\mathrm{n}= & \text { jumlah kartu dalam kombinasi }
\end{aligned}
$$

Apabila pemain tidak mengeluarkan kartu (pass) maka nilai $\mathrm{K}$ akan diisi dengan -65 , dan bila lawan tidak mengeluarkan kartu maka nilai $\mathrm{K}$ akan diisi dengan 0 . Sebagai contoh apabila dalam hand pemain terdapat kartu 3. dan 3s, kemungkinan kombinasi kartu yang dapat

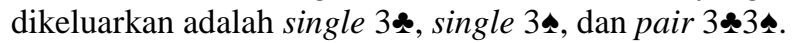

$$
\begin{array}{lll}
\mathrm{C}(3 *)=(3 * 4)+2=14 \rightarrow & \mathrm{K}(3 *)=14 \\
\mathrm{C}(3)=(3 * 4)+4=16 \rightarrow \mathrm{K}(3)=16 \\
\mathrm{~K}(3+3)=14+16=30 \text { (tertinggi) }
\end{array}
$$

\section{Perhitungan Nilai Evaluasi}

Rangkaian proses yang dilakukan adalah pertama-tama pemain mengeluarkan kartu, kemudian lawan (virtual hand) akan mengeluarkan kartu. Karena terdapat 3 lawan pemain, maka virtual hand melakukan langkah sebanyak 3 kali, Kemudian pemain kembali mengeluarkan kartu. Lalu dengan menjumlahkan nilai keseluruhan dari tiap node, akan didapat nilai evaluasi (SBE) dilambangkan dengan V. Istilah node digunakan untuk menunjukkan setiap nilai dalam kombinasi kemungkinan dari setiap virtual hand pada setiap giliran melangkah. 


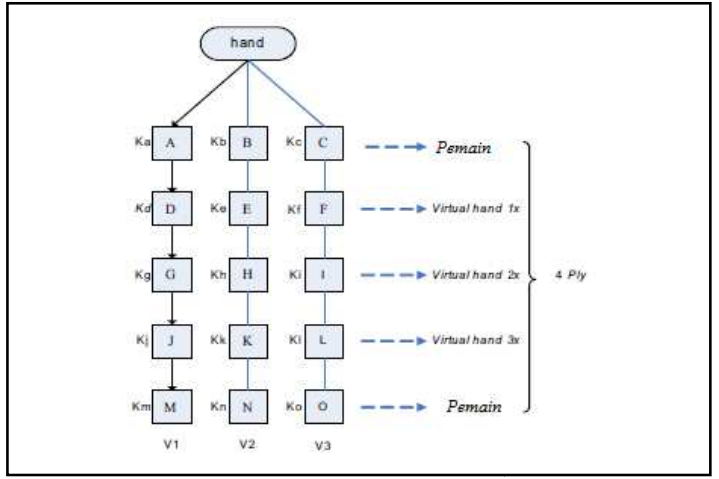

Gambar 8. Skema Perhitungan Value

$\mathrm{V} 1=\mathrm{Ka}-\mathrm{Kd}-\mathrm{Kg}-\mathrm{K} \mathrm{j}+\mathrm{Km}$

$\mathrm{V} 2=\mathrm{Kb}-\mathrm{Ke}-\mathrm{Kh}-\mathrm{Kk}+\mathrm{Kn}$

$\mathrm{V} 3=\mathrm{Kc}-\mathrm{Kf}-\mathrm{Ki}-\mathrm{Kl}+\mathrm{Ko}$

Dari hasil perhitungan fungsi evaluasi, pemain harus mengambil nilai node yang terbesar. Sebagai contoh apabila hand pemain adalah $9 * \mathrm{~J} * \mathrm{~A}$, dan lawan / virtual hand

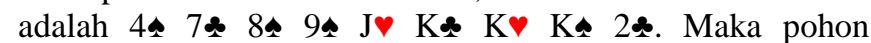
Minimax yang terbentuk adalah sebagai berikut:

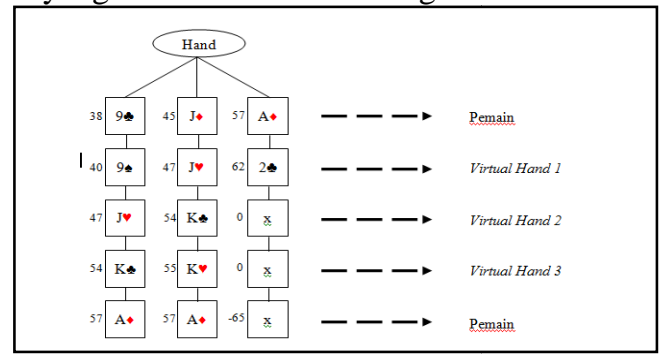

Gambar 9. Pohon Perhitungan Langkah yang Diambil
Dari contoh gambar diatas, maka pemain akan mengambil jalur permainan dengan nilai fungsi evaluasi yang terbesar (46), yaitu dengan membuang kartu single 9 9.

\section{KESIMPULAN}

1. Adobe Flash Builder dan framework starling dapat digunakan untuk mengembangkan aplikasi mobile berbasis Android.

2. Semua mode permainan (Normal, King \& Slave, dan Relax) baik secara offline dan online dapat berjalan dengan baik.

3. Diperlukan tambahan Native Extension untuk menghubungkan aplikasi berbasis AIR dengan layanan google play games services.

4. Algoritma Alpha Beta Pruning dapat digunakan untuk membuat kecerdasan buatan pada permainan kartu capsa banting.

\section{REFERENSI}

[1] McLeod, John. 2007. Rules of Card Games: Big Two, Access.

[2] Kusumadewi, Sri. 2003. Artificial Intelligence (Teknik dan aplikasinya). Yogyakarta: Graha Ilmu.

[3] Barr, Avron, and Edward A. Feigenbaum. 1982. The Handbook of Artificial Intelligence. Stanford: Heuris Tech Press.

[4] Rich, E. dan K. Knight. 1991. Artificial Intelligence. New York: McGraw-Hill, Inc.

[5] Prasetyo, Bambang dan Lina Miftahul Jannah. 2010. Metode Penelitian Kuantitatif Teori dan Aplikasi. Jakarta: Raja Grafindo Persada.

[6] Y. Yorozu, M. Hirano, K. Oka, and Y. Tagawa, "Electron spectroscopy studies on magneto-optical media and plastic substrate interface,” IEEE Transl. J. Magn. Japan, vol. 2, pp. 740-741, August 1987 [Digests 9th Annual Conf. Magnetics Japan, p. 301, 1982].

[7] M. Young, The Technical Writer's Handbook. Mill Valley, CA: University Science, 1989. 